\title{
CORRELATION OF OBJECTIVE AND SUBJECTIVE PARAMETERS IN RESEARCH OF URBAN GREEN SPACES ACCESSIBILITY ON THE EXAMPLE OF BRATISLAVA
}

\author{
Peter Baus, IVANA KoHUtKovÁ, RAstislav KrivosudskÝ \\ Department of Landscape Ecology, Comenius University in Bratislava, Faculty of Natural \\ Sciences, Mlynská dolina, 84215 Bratislava, Slovakia, e-mail: baus@fns.uniba.sk, \\ kohutkova@fns.uniba.sk, krivosudsky@fns.uniba.sk
}

Received: $11^{\text {th }}$ April 2011, Accepted: $27^{\text {th }}$ May 2012

\begin{abstract}
The article deals with the accessibility of urban green spaces in Bratislava city. These areas are considered to be a significant part of urban environment as they fulfil many crucial functions. The research is focused on greenery of Bratislava - an important landshaping component of urban landscape - which influences residents' quality of life as a place for regeneration and rest. The main goal of the research is evaluation of green urban spaces accessibility in Bratislava from the time perspective by different types of transport using a questionnaire survey and available network analysis method. We use correlations of objective data gained by network analysis and subjective data obtained from the questionnaire survey. By using these methods, we were able to determine areas within Bratislava city specific in high or low correlation results. These results may be used in urban planning process focused on urban green spaces distribution.
\end{abstract}

Key words: urban green spaces; accessibility; Bratislava city, network analysis; questionnaire.

\section{INTRODUCTION}

Urban green spaces have been designated in the cities since the 1880s in order to avoid the environmental impacts of urban expansion and intensification. Urban green spaces are public green areas, mostly covered by vegetation and situated in the urban space. First of all, these areas serve as places for active or passive recreation and in general, they also have positive effects on urban setting (Reháčková and Pauditšová 2006). Plants, notably trees, provide a wide range of environmental benefits and functions, and urban green spaces often accommodate varied assemblages of flora and small animals, providing readily accessible sites with natural ingredients or surrogates of nature for the enjoyment of the people who are otherwise detached from nature (Liu and Liu 2008: 353).

When we think about the cities in terms of competitiveness, in international meaning, one of the major aspects to take into account is the presence of public facilities such as urban parks or various types of green spaces. Another significant aspect is the accessibility to these green spaces. These notions can be viewed as differences between an industrial society, in which the primary focus is on economic efficiency and productivity, versus 
a more cultural oriented society where a higher quality of life is prioritized (Oh and Jeong 2007).

Urban green spaces play a central role, both physically and functionally, in urban planning and development (Pasaogullari and Doratli 2004). They support urban ecological and social systems: a fact recognised in public policy commitments in Europe. Provision, the distribution of green space and the ease of access to such spaces are the key contributors to social and ecological function in urban environments. The condition of urban green spaces underpins the functionality of urban ecosystems. Urban green spaces play a key role in maintenance or restoration of biodiversity and provide important ecosystem services in urban areas (Gaston et al. 2005). Many urban theorists state the significance of urban green spaces as one of the principal components of a healthy urban setting (Pasaogullari and Doratli 2004).

Recently, they have become less significant, because they are neglected in the urban planning process or because so of them are lost. Additionally, accessibility and utilization of these areas decreases, since urban green spaces have been neglected in urban planning and development processes. Accessibility and utilization of urban green spaces and their physical and functional structures are among the issues that are negatively affected by rapid urban growth. Especially in developing economies, green spaces in urban settlements are far behind reaching the contemporary standards of better endowed cities (Pasaogullari and Doratli 2004).

Many studies demonstrated that the quality and accessibility of green spaces are, from the social perspective, more important factors than their numbers in a particular area. Hence, the accessibility of green spaces in urban areas is considered to be a significant indicator of quality of life assessment (Reháčková and Pauditšová 2006).

Accessibility is a frequently-used concept but there is no consensus about its definition and formulation. It is a common term experienced by various individuals (i.e. characterised by different needs, abilities and opportunities) at any place and moment of the day, which results in considerable variation in components included in the measure, and in how it is formulated (Vandenbulcke et al. 2009: 40).

According to Lau and Chiu (2003: 197) accessibility is defined as the freedom or ability of people to achieve their basic needs in order to sustain their quality of life. In Europe, the European Environment Agency (EEA) recommends that people should have access to green space within 15 minutes walking distance (Barbosa et al. 2007). English Nature (now Natural England) provides a set of standards for evaluating the provision of and access to natural places in the Accessible Natural Greenspace Standards (ANGSt). The ANGSt model specifies guidelines for greenspace access provision (Comber et al. 2008: 104):

- No person should live more than $300 \mathrm{~m}$ from their nearest area of natural green space of at least $2 \mathrm{ha}$ in size.

- There should be at least one accessible 20 ha site within $2 \mathrm{~km}$ from home.

- There should be one accessible 100 ha site within $5 \mathrm{~km}$.

- There should be one accessible 500ha site within $10 \mathrm{~km}$.

This model was developed in the early 1990s and was based on research into minimum distances people would travel to the natural environment. However, no scientific publication could be found specifically discussing this model. According to the authors' research a number of issues raised which were seen as problems for the implementation of the ANGSt model. The main difficulty was seen in the lack of clear guidance for the application of the model (Handley et al. 2003). Although the distances and areas did not match any logical order, model gives us the basic view or guideline for people's needs within the green spaces in measurable variables. During our research we followed the 
mathematical order of numbers. We established $450 \mathrm{~m}$ distance as a limit which is approximately 5 minutes walking distance.

Based on the stated above, we may agree with Calthorpe (1993 in Pasaogullari and Doratli 2004: 226) that public parks and similar areas are fundamental features of livable and enjoyable higher-density communities.

The aim of our research is to find out the correlation between the subjective opinions of Bratislava inhabitants and objective data relating to the distance between their homes and the urban green spaces. The selected method has the potential to provide a tool for optimalization of urban green spaces network and inhabitants satisfaction with it.

\section{MATERials}

\section{The model area}

Bratislava, the capital city of the Slovak Republic, was selected as a model area for the analysis of urban green spaces accessibility. Bratislava is situated in the south-western part of Slovakia, between the Danubian Plain and the Small Carpathians Mountains, near to the border with Hungary and Austria.The altitude of the city ranges from $125 \mathrm{~m}$ to $514 \mathrm{~m}$ (Mazúr and Lukniš 1986).

According to administrative divisions, the city belongs to Bratislava County and is divided into 5 districts and 17 city parts $(\mathrm{CP})$. The area of Bratislava reaches approximately $368 \mathrm{~km}^{2}$ with the population of 429,000 people. The average density is of 1,166 inhabitants per square kilometer (Štatistický úrad SR 2009).

Relating to the means of transport, cars, public transport, bicycle and walking are the most utilized means when people move from one place to another across Bratislava (Magistrát hlavného mesta SR Bratislavy 1996). Due to the status of capital city, its geographical location, proximity of Vienna (the capital of Austria) and Budapest (the capital of Hungary) and high number of unbuilt areas, it represents one of the fastest growing cities in Central Europe.

\section{Urban greenery in Bratislava}

We chose 28 urban green places, which are accessible to the public and fulfil the recreation function and 11 entry points to forests and forestparks. The selection and characteristics of particular areas follows the publications of Reháčková and Pauditšová (2003, 2004, 2006), Reháčková et al. (2007) and Reháčková (2009) specialized in urban greenery analysis in Bratislava. We define the minimum area of green spaces as 0.5 ha and we also consider the significance and visit rate of the places.

Selected urban green spaces are divided into following categories (Reháčková and Pauditšová 2003):

Parks, arboretums and ZOOs;

Landscaped areas around housing estates;

Historical cemeteries;

Forests and forestparks (see table 1).

Within the first category, the ZOOs were not taken into the consideration as the research targeted parks and arboretums only. Parks are representational and significant areas with interesting composition of species, landscaped areas around housing estates with existing paths. They are covered by planted trees and shrubs, various flower decorations and mobiliari (benches, fountains, sculptures, etc.). The recreational, aesthetic and ecological 
functions prevail. Parks are divided into two categories - historical and modern parks. Historical types of parks comprise of various garden styles with high cultural value in general. Modern parks have been established within the landscaped surroundings of new blocks of flats in 1960's - 1980's.

Table 1: Categories of surveyed urban green spaces in Bratislava

\begin{tabular}{|c|c|}
\hline \multirow{16}{*}{ Parks and arboretums } & Grassalkovičová záhrada garden \\
\hline & Medická záhrada garden \\
\hline & Sad Janka Krála park \\
\hline & Park near the castle \\
\hline & "Horsky" park \\
\hline & Žatevná-Pekniková park \\
\hline & Detvianska park \\
\hline & Ostredkova park \\
\hline & Andrej Hlinka's park \\
\hline & Kvačalova park \\
\hline & L’udové námestie plaza \\
\hline & Račianske mýto park \\
\hline & Námestie slobody plaza \\
\hline & Jakubovo námestie square \\
\hline & Kmet’ovo námestie square \\
\hline & Kalvária \\
\hline \multirow{12}{*}{$\begin{array}{l}\text { Significant orchard-like } \\
\text { modified areas }\end{array}$} & Tyršovo nábrežie riverbank \\
\hline & Vrútocká \\
\hline & Štrkovecké jazero lake \\
\hline & Kuchajda lake \\
\hline & Prikopova street \\
\hline & Šafárikovo námestie plaza \\
\hline & Kolárovo námestie plaza \\
\hline & Vajanského nábrežie riverbank \\
\hline & Riverbank of shopping centre "Galleria Eurovea" \\
\hline & Castle's hill and surroundings \\
\hline & Dunajská street \\
\hline & Hviezdoslavovo námestie plaza \\
\hline Historical cemeteries & Ondrejský cintorín cemetery \\
\hline \multirow{11}{*}{ Forests and forest parks } & Rača - Knižkova dolina valley \\
\hline & Rača-Kopanice \\
\hline & Krasňany - Pekná cesta \\
\hline & Nové Mesto-Ahoj, Sliačska \\
\hline & Železná studnička - Červený most \\
\hline & Cesta na Kamzík \\
\hline & Lamač \\
\hline & Dúbravka-Church \\
\hline & Dúbravka-Brižitská \\
\hline & Karlova Ves - Králov vrch \\
\hline & Karlova Ves - Sološnícka \\
\hline
\end{tabular}

Second category includes areas which do not match the criteria for parks, where the greenery within blocks of flats is dominant. Their primary function is short-term recreation 
in proximate people's home surroundings (with components of benches and playgrounds including sandpiles, climbing frames, etc.). Furthermore, the research was focused on landscaped areas near water courses.

Historical cemeteries, belonging to the third category, are areas with a reverent character with long history and typically rich in greenery. They are popular due to the recreational and ecological functions what means they serve more as parks than cemeteries.

Forests and forest parks, in the fourth category, comprise of the forest land fund and are characterized by the presence of natural or nature close vegetation. These areas are situated mostly in the marginal parts of urban settings. The ecological function (especially when they are part of a protected area) is dominant, although the additional recreational function is also important. In city parts Vajnory, Rača, New Town and Záhorská Bystrica, the surveyed areas are part of Small Carpathians Mts. Protected Landscape Area. Moreover, for the purpose of our research we added 11 entry points to the forests and forestparks in the Bratislava surrounding because the data gained during the questionnaire survey show high satisfaction of residents, who live near the forests or forest parks, with urban green spaces. This fact suggests that respondents consider forests and forestparks to be a significant part of urban green spaces.

\section{METHODS}

Our research was carried out in several phases. In the first step, we realized the questionnaire survey among Bratislava citizens (people with permanent or temporary address in the city). The questionnaire form consisted of simple closed questions. Moreover, respondents were also asked to provide their address. In order to maintain respondents' anonymity, they covered only the name of the street they live in. This allowed us to allocate individual answers to almost exact geographical location within the city. The geographical location was generated through the Google Maps API application. It also allows to measure the network distance between two geographical points and enabled us to calculate the time needed for moving between these points by certain means of transport. We identified the entire list of urban green spaces of Bratislava and for each position we conducted a network analysis of accessibility from respondents' addresses and chose the nearest green area.

Thereby, we obtained data relating to time needed for walk (in seconds) from respondent's home to each urban green space in Bratislava which were inserted into the database. Then we were able to find out what time each respondent needs to reach the nearest green space. According to Barbosa et al. (2007) we set the average value of intervals to 15 minutes (900 seconds). We divided data relating to accessibility, collected from all respondents, to four intervals: 0 - 450; 451 - 900; 901 - 1350; 1351 - $\infty$. Moreover, we divided the answers into four categories and afterwards, compared questionnaire results with the network analysis results in the virtual settings by GIS tools.

\section{RESULTS}

\section{Questionnaire survey}

Questionnaire survey was carried out among 428 citizens of Bratislava. Respondents were selected randomly, however with the requirement of visiting the urban green space at least occasionally. The questionnaire included six questions related to the quality and 
accessibility of urban green spaces. However, for purposes of this article we present results of only two of them:

1. What kind of transport do you use when you visit urban green spaces? (Options: bicycle, public transport, car, walking)

2. Are you satisfied with the accessibility of parks in the surroundings of your home? (Options: very satisfied, satisfied, less satisfied, not satisfied)

The results showed that most of the respondents $(66 \%)$ walk or take public transport (25 $\%$ ) when they feel the need to visit green spaces. Only $5 \%$ of them use the bicycle and $4 \%$ go by car. Due to these facts, the research was focused especially on the walking accessibility. Regarding the satisfaction with accessibility to the green areas, $42 \%$ of respondents were satisfied, $24 \%$ of them were very satisfied and $26 \%$ were less satisfied. Only $8 \%$ of them were not satisfied.

\section{Network analysis}

The distance between geographical location of respondents' home and location of each green space was measured in the Google Maps API application. Data were defined in seconds because the application is able to estimate the approximate time needed to walk between two selected points.

Obtained data ranged between 79 and 3932 seconds. The average value was 938.86 seconds, what means that the average time needed to walk from respondents' home to the nearest green area is approximately 15.6 minutes. However, in real settings the number is likely to be lower because the network of roads, used within selected methodical approach, does not include footpaths, byways, walk-throughs, etc., which can make the walk quicker. Creation of such complete network would be extremely demanding hence the road network is recently the optimal available alternative.

\section{Correlation analysis}

Results of questionnaire and network analysis research were analysed by statistical method of correlation coefficient in MS Excel 2010. Consequential correlation coefficient of these two data sets was 0.12 which we consider as low or no correlation. This would mean that we were not able to achieve results through the selected method which would have mutual coherence with respondent's opinions and the distance from their homes to the urban green spaces. Despite of this fact, we were convinced that the mutual connection between data exists. Therefore, we attempt to apply the spatial element in detection of mutual correlation.

As stated above, data gained by network analysis were divided into four intervals. By this, we obtained (along with questionnaire results) two types of data that were comparable. We detected the correlation between respondents' opinions and computed distance to the nearest urban green space. We regarded the correlation as very high when one of the four eventual respondents' answers was in accordance with the network analysis interval. If they differ in one degree it was regarded as a high correlation, if the difference was in two degrees it was considered as a low correlation. And in the case of difference in three degrees and more there was no correlation.

The results of the research are displayed in Figure 1 where the level of correlation is represented by colour scale. Through the display we revealed the hidden pattern. The colour of each point determines the level of its correlation. In the map, areas with the different levels of correlation are clearly identified. 
Fig.1: Respondent's address position and correlation between their opinion and their distance to nearest urban green space in Bratislava

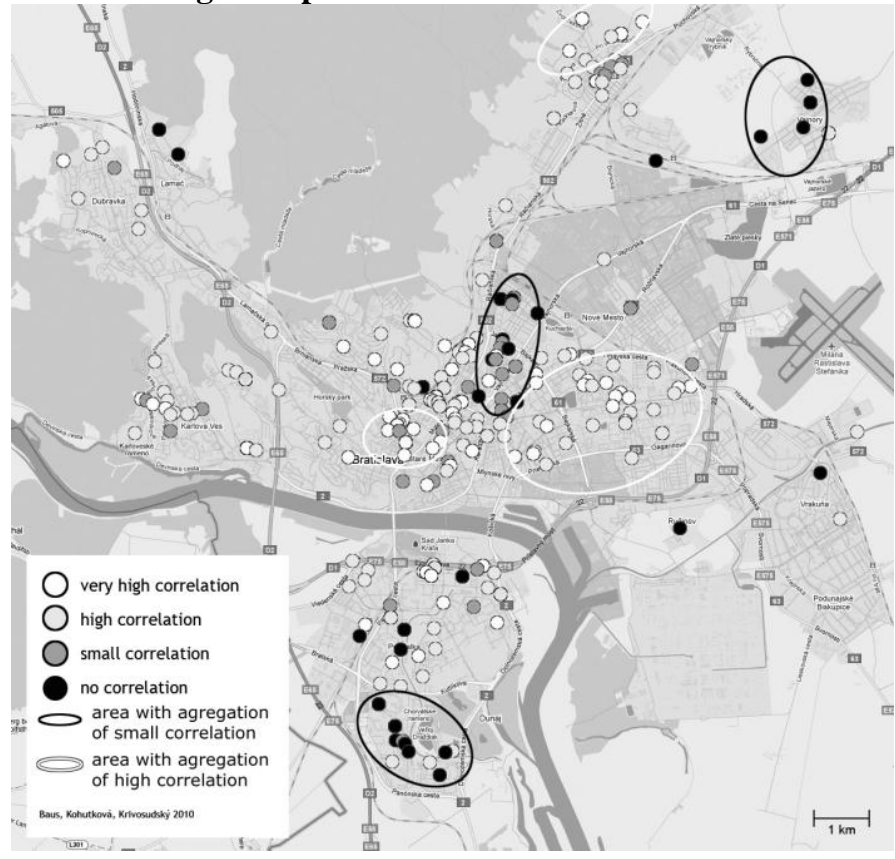

\section{DISCUSSION}

Partial spatial orderliness of correlations in terms of urban space leads us to deduction that the selected approach was appropriate and of value. We can allege that the opinions of respondents largely depend on the real distance between their home and the closest urban green space, although they are affected by other variables. High correlation in some areas indicated that it is feasible (by improvement of the methodical approach) to simulate the opinions of inhabitants towards the green space accessibility in urban space with sufficient accuracy only with data gained from aerial photos. Opinions of residents are unpredictable because they are influenced by a broad range of factors - from macro-local conditions and settlement characteristics to their psychological profiles.

The results obtained by this method are not required to achieve the perfect correlation, but can be an instrument for data acquisition by simpler and cheaper methods. Similar instruments would be exercisable in urban greenery planning and decision-making related to urban parks, park areas and greenery in general.

\section{CONCLUSIONS}

The undertaken research showed unexpected results. We can state that the perception of accessibility of urban green spaces depends on the real walking distance to the nearest green area, but also on the general perception of the inhabitants' environment and their personal characteristics. We combined classic methodological approaches - GIS and sociological research. Presented type of research might be of high importance, mainly in 
studies focused on city areas, when taking into account the urban areas affected by both, physical conditions and human activities. From the perspective of different disciplines, combination of these approaches may lead to better understanding of urban processes and people living in urban environment.

\section{REFERENCES}

Barbosa, O., Tratalos, J.A., Armsworth, P.R., Davies, R.G., Fuller, R.A., Johnson, P. \& Gaston, K.J. (2007). Who benefits from access to green space? A case study from Sheffield, UK. Landscape and Urban Planning, 83 (2-3): 187-195;

Štatistický úrad SR (2009). Štatistická ročenka hlavného mesta SR Bratislavy. Štatistický úrad SR, Bratislava, Slovakia;

Calthorpe, P. (1993). The Next American Metropolis. In Pasaogullari, N., Doratli, N. (2004): Measuring accessibility and utilization of public spaces in Famagusta Cities. Cities, 21 (3): 225-232;

Comber, A., Brunsdon, Ch. \& Green, E. (2008). Using a GIS-based network analysis to determine urban greenspace accessibility for different ethnic and religious groups. Landscape and Urban Planning, 86 (1): 103-114;

Gaston, K.J., Warren, P.H., Thompson, K. \& Smith, R.M. (2005). Urban domestic gardens (IV): the etxtent of the resource and its associated features. Biodiversity and conservation, 14: 3327-3349;

Handley, J., Pauleit, S., Slinn, P., Barber, A., Baker, M., Jones, C. \& Lindley, S. (2003). Accessible Natural Green Space Standards in Towns and Cities: A Review and Toolkit for their Implementation. English Nature Research Report Number 526. English Nature, Peterborough, UK, 97 pp.

Oh, K., Jeong, S. (2007). Assessing the spatial distribution of urban parks using GIS. Landscape and Urban Planning, 82 (1-2): 25-32;

Lau, J.C.Y., Chiu, C.C.H. (2003). Accessibility of low-income workers in Hong Kong. Cities, 20 (3): 197-204;

Liu, S., Liu, B. (2008). Using GIS to Assess the Ecological-niche for Urban Green Space Planning in Wuxi City. Retrieved February 2011, from http://www.kolleg.loel.hsanhalt.de/landschafts informatik/fileadmin/user_upload/_temp_/2008/2008_Beitraege/ 004/Buh_353-363.pdf

Magistrát hlavného mesta SR Bratislavy (1996). Územný plán hlavného mesta SR Bratislavy - Prieskumy a rozbory. Oddelenie tvorby mesta a oddelenie odvetvových generelov, Bratislava, Slovakia.

Mazúr, E., Lukniš, M. (1986). Geomorfologické členenie SSR a ČSSR. Čast' Slovensko. Slovenská kartografia, Bratislava

Pasaogullari, N., Doratli, N. (2004). Measuring accessibility and utilization of public spaces in Famagusta Cities. Cities, 21 (3): 225-232;

Reháčková, T. (2009). Cudzokrajné druhy drevín v historických parkoch Bratislavy. Cicero, Bratislava, Slovakia;

Reháčková T., Pauditšová E. (2003). Priemet najvýznamnejších plôch zelene na území Bratislavy - podklad pre návrh územného plánu. Magistrát hlavného mesta, Bratislava, Slovakia 
Reháčková, T., Pauditšová, E. (2004). Evolution of green spaces in Bratislava. Boreal Environment Research, 9: 469-477;

Reháčková, T., Pauditšová, E. (2006). Vegetácia v urbánnom prostredí. Cicero, Bratislava, Slovakia;

Reháčková, T., Lehotská, B., Nevřelová, M., Pauditšová, E. \& Ružičková, J. (2007). Fragmenty lesov v zastavanom území Bratislavy. Cicero, Bratislava, Slovakia

Vandenbulcke, G., Steenberghen, T. \& Thomas, I. (2009). Mapping accessibility in Belgium: a tool for land-use and transport planning? Journal of Transport Geography, 17 (1): 39-53; 